\title{
O CONCEITO CONSTITUCIONAL DE FAMIILIA E SUA CAPACIDADE PROCESSUAL: DO ALCANCE DA COISA JULGADA A TODOS OS SEUS INTEGRANTES
}

\author{
THE CONSTITUTIONAL CONCEPT OF FAMILY AND ITS PROCEDURAL CAPACITY: THE SCOPE OF \\ RES JUDICATA TO ALL ITS MEMBERS \\ EL CONCEPTO CONSTITUCIONAL DE FAMILIA Y SU CAPACIDAD PROCESAL: DEL ALCANCE DE LA \\ COSA JUZGADA A TODOS SUS INTEGRANTES
}

Luiz Carlos Goiabeira Rosa ${ }^{1}$

\section{RESUMO}

O presente artigo presta-se a tecer comentários sobre o conceito constitucional de família e, a partir de tal parâmetro, constatar que a família pode ser considerada ente único em algumas situações. Por meio dos métodos indutivo e dialético, comprovar-se-á que a família pode ser detentora de capacidade processual, sendo assim parte numa relação jurídica processual; e bem assim, observar-se-á a necessidade de se alterar o art. 12 do Código de Processo Civil, acrescentando-se a família no rol do mencionado dispositivo.

PALAVRAS-ChAVE: Família. Capacidade processual. Ente despersonalizado. Coisa julgada.

\section{ABSTRACT}

This article offers some commentaries on the constitutional concept of family, and based on this parameter, it observes that family can be considered as a single entity in certain situations. Through the inductive and dialectical methods, it demonstrates that the family can be a holder of procedural capacity, making it part of a procedural legal relationship. It also notes the need to change article 12 of the Civil Procedure Code, adding the family in the list of provisions mentioned.

KEYWORDS: Family. Procedural capacity. Depersonalized entity. Res judicata.

\section{RESUMEN}

El presente artículo se propone elaborar comentarios sobre el concepto constitucional de familia y, a partir de tal parámetro, constatar que la familia puede ser considerada ente único en algunas situaciones. Por medio de los métodos inductivo y dialéctico se comprobará que la familia puede ser detentadora de capacidad procesal, siendo así parte en una relación jurídica procesal; de la misma manera, se observará la necesidad de alterar el art. 12 del Código de Proceso Civil, agregando a la familia en el rol del mencionado dispositivo.

1 Mestre em Direito Civil pela Universidade Federal de Minas Gerais (UFMG). Doutor em Direito Privado pela Pontifícia Universidade Católica de Minas Gerais (PUC Minas). Professor da Universidade Federal de Uberlândia - Faculdade de Ciências Integradas do Pontal (UFU/FACIP), na cidade de Ituiutaba - MG. goiabeira@pontal.ufu.br; Igoiabeira@yahoo.com.br 
PALABRAS CLAVE: Familia. Capacidad procesal. Ente despersonalizado. Cosa juzgada.

\title{
INTRODUÇÃO
}

Conforme a principiologia constitucional, a coisa julgada não pode ser prejudicada pela lei. Ato contínuo, por um imperativo de ordem processual da respectiva decisão da res iudicata não cabe mais recurso.

Contudo hipóteses há em que a coisa julgada estende-se a terceiros não participantes da lide, porém interessados no resultado, necessitando-se para tanto enxergar um grupo de pessoas como ente único. De tais situações, o presente estudo abordará a questão da família como ente em si considerado e demonstrará a necessidade de tal configuração para fins materiais e processuais: por meio do método dedutivo, demonstrar-se-á que a família pode ser considerada um ente despersonalizado e, por consequência, dotada de capacidade processual em determinados casos, fato já reconhecido e adotado jurisprudencialmente.

Para tanto, discutir-se-á sobre a amplitude do impacto da coisa julgada em relação à família, ainda que a decisão tenha envolvido diretamente somente um ou alguns de seus membros. Observar-se-á a flagrante discrepância entre o interesse da família defendido por mais de um membro sucessivas vezes, em contraposição à única vez de que dispõe a parte adversa. Ao fim, concluir-se-á pela necessidade de se alterar preceitos do Código de Processo Civil, incluindo-se entre os sujeitos de direito processual a família na acepção constitucional, representada por qualquer um de seus membros.

\section{DOS ENTES DESPERSONALIZADOS COMO SUJEITOS DE DIREITO}

A moderna doutrina tem entendido a personalidade como o conjunto de atributos reconhecidos juridicamente, que permitem a um sujeito de direito a participação em relações jurídicas de forma a se adquirir, possuir ou extinguir direitos e contrair ou extinguir obrigações na esfera civil. Esse conjunto consubstancia-se num valor e não num direito, conforme preleciona Telles Junior citado por Diniz:

\begin{abstract}
A personalidade consiste no conjunto de caracteres próprios da pessoa. A personalidade não é um direito, de modo que seria errôneo afirmar que o ser humano tem direito à personalidade. [...] A personalidade é o que apóia os direitos e deveres que dela irradiam, é objeto de direito, é o primeiro bem da pessoa, que lhe pertence como primeira utilidade, para que ela possa ser o que é, para sobreviver e se adaptar às condições do ambiente em que se encontra, servindo-lhe de critério para aferir, adquirir e ordenar outros bens. ${ }^{2}$
\end{abstract}

Amaral, em brilhante explicação acerca da distinção entre personalidade e capacidade, entende que, enquanto a personalidade consubstancia-se num valor, a capacidade é a projeção desse valor que se traduz em uma quantidade, um quantum: "[...] enquanto a personalidade é valor ético que emana do próprio indivíduo, a capacidade é atribuída pelo ordenamento jurídico como realização desse valor". ${ }^{3}$

Ou seja: a capacidade seria a concretização dos valores integrantes da personalidade. E esta, ao seu turno, seria mais que mero aspecto formal da pessoa; seria um conjunto de atributos e valores jurídicos que permitiriam a alguém ser titular de relações jurídicas e, consequentemente, de direitos e obrigações.

Inobstante, considerável parte da doutrina ainda se refere à personalidade nos moldes liberalistas, definindo-a como a aptidão genérica para adquirir direitos e contrair obrigações, conforme previa o art. $2^{\circ}$ da Lei n 3.071/1916, de 01 de janeiro de 1916 (Código Civil de 1916). Em razão disto, se um sujeito de direito tem aptidão para adquirir apenas alguns direitos e contrair algumas obrigações, não seria pessoa.

2 DINIZ, Maria Helena. Compêndio de Introdução à Ciência do Direito. 15. ed. São Paulo: Saraiva, 2003, p. 119.

3 AMARAL, Francisco. Direito Civil - Introdução. 3. ed. Rio de Janeiro: Renovar, 2000, p. 216. 
Insta observar que a aptidão para adquirir direitos e contrair obrigações relaciona-se com a capacidade, posto esta ser uma espécie de materialização da personalidade. Esta, por sua vez, seria o conjunto sistematizado de atributos e valores do sujeito de direito que serviria de fundamento e substrato à aptidão para aquisição de direitos e obrigações.

Quer se dizer com isso que um sujeito de direito será pessoa se reunir determinados atributos humanísticos, e não necessariamente se tiver aptidão genérica para aquisição de direitos e obrigações. Tanto o é, que há um crescente entendimento doutrinário segundo o qual o nascituro seria pessoa desde a concepção, pois já detentor de atributos que o Estado deve proteger e tutelar - entre eles, a dignidade.

Por consequência, seria a capacidade, e não a personalidade, que variaria conforme a relação jurídica da qual o ente participasse: a maior ou a menor extensão da aptidão para aquisição de direitos e obrigações seria verificada na delimitação do exercício da personalidade, e não nesta em si considerada. Conforme entende Alpa, a relação jurídica é travada "entre dois ou mais sujeitos entre si ou com uma coisa, à qual o ordenamento jurídico atribui relevância", em que tal "coisa" poderia ser tomada pelo conjunto de atributos essenciais ao ser humano para viver dignamente em sociedade. ${ }^{4}$

É dizer: entendida a personalidade sob o ponto de vista formalista, numa relação jurídica sujeitos de direito só participariam se dotados de aptidão genérica para adquirirem direitos e contraírem obrigações. Então não haveria direitos "da personalidade" na medida em que somente os há após haver juridicamente uma personalidade em vigência. Então, os "direitos da personalidade" não poderiam existir antes desta ou após a extinção desta.

Entrementes, repita-se: a personalidade não é a aptidão genérica para adquirir direitos e obrigações, mas sim o arcabouço sistematizado de valores e atributos que legitimam e permitem ao sujeito de direito a aquisição de direitos e obrigações - esta, materializada na capacidade. A personalidade é o que apoia os direitos que dela irradiam - aí se vendo então a aquisição de direitos e obrigações e seu respectivo exercício (capacidade).

A própria Lei n 10.406/02, de 10 de janeiro de 2002 (Código Civil de 2002), traça casos em que os direitos da personalidade existem juridicamente antes e após a vigência da personalidade - por exemplo, no caso do nascituro (art. $2^{\circ}$ ) e do falecido (art. 12, parágrafo único). Conclui-se, assim, que a pessoa tem o direito de exercer os atributos da personalidade tutelados pelo Direito não por ter aptidão para adquirir direitos e contrair obrigações, mas por ter atributos essenciais à existência do ser humano, reconhecidos e protegidos pelo ordenamento jurídico. Conforme bem aponta Perlingieri, tocante aos direitos da personalidade, a questão não pode ser tratada como um direito subjetivo elaborado à base da categoria do "ter", posto que se insira na categoria do "ser". 5

Por consequência, o que se convencionou denominar "direitos da personalidade" refere-se em verdade aos atributos que constituem a essência da individualidade humana, sem os quais o ser humano não poderia ser considerado indivíduo e muito menos pessoa: são caracteres axiomáticos, inerentes ao próprio ontos humano e com múltiplos conteúdos. Assim, o que se chama de "direitos da personalidade" na verdade são atributos do ser humano, na medida em que são características intrínsecas e essenciais do ser humano filosoficamente considerado - ou seja, mesmo antes deste adquirir personalidade.

Isto posto, deve-se atentar à impropriedade da forma pela qual os tradicionalistas abordam a personalidade como requisito para participação numa relação jurídica - e bem assim, para a aquisição dos direitos da personalidade -: esta não necessariamente deve ser verificada, para se ter numa relação jurídica a titularidade de direitos da personalidade. Fosse necessária, e os entes despersonalizados, tais quais o nascituro ou a massa falida não poderiam gozar da proteção ao nome, à imagem ou a outros direitos.

Em outras palavras: é errôneo, por exemplo, concluir-se que, mesmo tendo aptidão para contrair direitos e obrigações ainda que restritamente, os chamados "entes despersonalizados"6 não sejam dotados de personalidade.

4 ALPA, Guido. Instituzioni di Diritto Privato. 2. ed. Torino: UTET, 1997, p. 213.

5 PERLINGIERI, Pietro. Perfis do Direito Civil: Introdução ao Direito Civil Constitucional. Rio de Janeiro: Renovar, 2000, p. 155.

6 É outra impropriedade terminológica. Se personalidade é a aptidão para adquirir direitos e contrair obrigações, e se o ente "despersonalizado" tem tais aptidões ainda que restritas a algumas relações jurídicas (por exemplo, na relação de consumo em que pode ser fornecedor, a teor do art. 12, parágrafo único do CC), então tem personalidade - e, portanto, não é "despersonalizado". 
Citado por Martins Costa, Santos da Cunha afirma ser por demais simplista entender personalidade como sinônimo de capacidade: isso seria retroceder aos ideais liberalistas, nos quais a pessoa era mais ou menos considerada capaz de acordo com o patrimônio que possuía. Deve-se atentar ao fato de que, ao mensurar a aptidão para adquirir direitos e contrair obrigações, a capacidade representa um corolário lógico de existência de aptidão para participação em relação jurídica, e não necessariamente personalidade. Por consequência, se um sujeito de direito pode participar de várias, algumas ou só uma relação jurídica, o fato é que possui aptidão para tanto - ou não teria capacidade para participar de um negócio jurídico. ${ }^{7}$

É dizer: onde há aptidão para adquirir direitos e obrigações, há capacidade porque é mister a delimitação de tal aptidão a bem da ordem social. Entretanto não necessariamente haverá personalidade, posto a capacidade poder dizer respeito a apenas alguns atributos do sujeito de direito, e ainda assim para determinada ou determinadas relações jurídicas.

Ou seja: a personalidade deve ser entendida como um conjunto de atributos do ser humano que o torna apto a ser sujeito de direitos e obrigações em todas as relações jurídicas na esfera civil. Contudo as respectivas benesses devem, quando possível, ser estendidas a outras figuras jurídicas se em tais se verificarem atributos da personalidade.

Esta é a razão pela qual uma coletividade de indivíduos ou outras agremiações sejam enxergadas como um ente único pelo Direito: uma vez que o ente reúna atributos que lhe permitam ser sujeito de direitos e obrigações na esfera civil, é reconhecido como pessoa ou ente despersonalizado pelo ordenamento jurídico conforme a amplitude de sua aptidão, pouco importando tratar-se de ente natural ou juridicamente considerado - ser humano ou coletividade abstrata.

Nesse mister, ensina a História que a pessoa jurídica nasceu da necessidade de se simplificar e otimizar as relações entre grupos de pessoas: o interesse comum de uma coletividade seria melhor e mais agilmente tratado se se considerasse essa coletividade como ente único, dotado de prerrogativas atinentes a direitos e obrigações. Nesse sentido, Venosa ensina que o surgimento das pessoas jurídicas se deu em meio à necessidade de atender a empreendimentos que a pessoa natural não mais atendia com plenitude:

O ser humano, pessoa física ou natural, é dotado de capacidade jurídica. No entanto, isoladamente
é pequeno demais para a realização de grandes empreendimentos. Desde cedo percebeu a
necessidade de conjugar esforços, de unir-se a outros homens, para realizar determinados
empreendimentos, conseguindo, por meio dessa união, uma polarização de atividades em torno
do grupo reunido. Daí decorre a atribuição de capacidade jurídica aos entes abstratos assim
constituídos, gerados pela vontade e necessidade do homem. As pessoas jurídicas surgem,
portanto, ora como conjunto de pessoas, ora como destinação patrimonial, com aptidão para
adquirir direitos e contrair obrigações. ${ }^{8}$

Referente a tal mister, o Direito pátrio reconheceu como pessoas jurídicas as coletividades previstas nos arts. 40 a 44 do Código Civil. Contudo, apesar de novamente surgir a necessidade de se simplificar as relações entre grupos de pessoas, não conferiu personalidade a outras coletividades existentes de fato, porém não de direito: não se atribuiu personalidade a grupos de pessoas ou de bens que correspondem a interesses de grupos aos quais a doutrina nomeou "entes despersonalizados", coletividades destituídas de personalidade por se entender que, por figurarem apenas em determinadas e ocasionais situações jurídicas, não necessitariam de aptidão plena para serem titulares de direitos e obrigações - razão pela qual o sistema jurídico confere-lhes tal aptidão somente em determinados casos.

Para Diniz:

Há entidades que não podem ser subsumidas ao regime legal das pessoas jurídicas do Código Civil, por thes faltarem requisitos imprescindíveis à subjetivação, embora possam agir, sem maiores dificuldades, ativa ou passivamente. São entes que se formam independentemente da vontade dos seus membros ou em virtude de um ato jurídico que vincula as pessoas físicas em torno de bens que Ihes suscitam interesses, sem Ihes traduzir affectio societatis. Donde se infere que os grupos despersonalizados ou com personificação anômala constituem uma comunhão de

7 Cf. MARTINS COSTA, Judith Hofmeister. O Direito Privado como um "sistema em construção": as cláusulas gerais no Projeto do Código Civil brasileiro. Jus Navigandi, <http://jus2.uol.com.br/ doutrina/ texto.asp?id=513>, maio de 2000.

8 VENOSA, Sílvio de Salvo. Direito civil: parte geral. 5. ed. São Paulo: Atlas, 2005, p. 255. 
interesses ou um conjunto de direitos e obrigações, de pessoas e de bens sem personalidade jurídica e com capacidade processual, mediante representação (CPC, art. 12). ${ }^{9}$

Em face de tal mister, somente em determinadas ocasiões especificadas pela lei os entes despersonalizados participariam de uma relação jurídica. Isto, aliado ao fato de que comumente as relações jurídicas dão-se entre pessoas, gerou um errôneo entendimento: o de que sujeito de direito e pessoa são sinônimos. De fato, a doutrina clássica entende ser relação jurídica aquela composta somente por pessoas em seus polos, apesar de tanto aquelas quanto os sujeitos de direito terem aptidão para adquirir direitos e contrair obrigações, guardadas as devidas proporções.

Respeitosamente, discordamos de tal entendimento doutrinário: como se aceitar o fato de que somente pessoas podem participar de uma relação jurídica, se desta o próprio sistema jurídico confere a entes destituídos de personalidade o direito de participarem? Por exemplo, o art. $3^{\circ}$ da Lei no 8.078/90 (Código de Defesa do Consumidor) elenca, entre outros, o ente despersonalizado como fornecedor, conferindo-se destarte a quem não é pessoa a faculdade de participar de uma relação jurídica.

O que se deve ponderar, em termos de relação jurídica, é o caráter objetivo que seus participantes possuem: como elementos estruturais, os sujeitos de direito guardam um grau de abstratividade, cujo conteúdo se especifica apenas quando concretizado. Ou seja: o sujeito de direito seria uma fórmula genérica, ao passo que a pessoa seria uma das concretizações de tal fórmula; se outro ente se enquadrar nos requisitos abstratos que perfazem um sujeito de direito, assim ele será.

O erro cometido pelos que defendem a sinonímia entre pessoa e sujeito de direito reside justamente na tentativa se de subjetivizar este. Acerca da subjetivização da relação jurídica, bem esclarece Gomes:

A maior dificuldade para defini-la promana da confusão entre o significado comum do vocábulo e o seu sentido técnico. Resulta, em grande parte, de falsa generalização. Uma vez que as relações jurídicas são predominantemente relações humanas, de pessoa para pessoa, de sujeito para sujeito, supõe-se que todas hão de ser um vínculo pessoal. De fato, a relação social é, por definição, a que se trava entre homens, mas isso não significa que o Direito rege apenas relações sociais, nem que outras sujeições, como a de coisa ao homem possam ter igual qualificação no vocábulo jurídico. Não há coincidência necessária entre relação humana e relação jurídica. ${ }^{10}$

Isto posto, certo é se considerar que a relação jurídica é aquela composta por sujeitos de direito, e não necessariamente por pessoas: será sujeito de direito qualquer um a quem a norma jurídica dotar de aptidão para praticar atos que gerem efeitos jurídicos em determinada relação jurídica. Para Coelho, nem todo sujeito de direito é pessoa, posto a lei auferir direitos a certos agregados patrimoniais, como o espólio ou a massa falida, sem personalizá-los; equivale a dizer que sujeito de direito é o ente detentor de direitos e obrigações conferidos pela norma jurídica, com vistas a se relacionar com outro ente para o fim de atender a necessidades e conveniências próprias e satisfazer as alheias - em face do que, nesse contexto, consideram-se também o ente despersonalizado sujeito de direito, posto possuir a aptidão ora mencionada ainda que limitadamente. ${ }^{11}$

É dizer: os entes despersonalizados diferem das pessoas unicamente porque estas possuem aptidão genérica para direitos, deveres e obrigações, ao passo que aqueles possuem tal aptidão limitada a determinadas relações jurídicas especificadas tanto pela legislação quanto por sua própria natureza. No entanto, guardadas as devidas proporções e limitações, ambos podem participar de uma relação jurídica como detentores de direitos e obrigações.

Isto posto, uma vez apto o ente despersonalizado a ser sujeito de direito, cumpre-se verificar se a família enquadra-se em ambos os contextos (ente despersonalizado e sujeito de direito).

9 DINIZ, Maria Helena. Curso de Direito Civil Brasileiro: teoria geral do direito civil. 24. ed. São Paulo: Saraiva, 2007, v. 1, p. 293.

10 GOMES, Orlando. Introdução ao direito civil. 16. ed. Rio de Janeiro: Forense, 2000, p. 95.

11 COELHO, Fabio Ulhoa. Curso de Direito Civil: Família, Sucessões. 2. ed. rev. e atual. São Paulo: Saraiva, 2009, vol. 5, p. 89. 


\title{
DA FAMÍLIA COMO ENTE DESPERSONALIZADO E SUJEITO DE DIREITO
}

Em Roma, "sob a liderança do pai, a família era o conglomerado composto da esposa, dos filhos, das filhas solteiras, das noras, dos netos e demais descendentes, além dos escravos e clientes". ${ }^{12} \mathrm{Na}$ Idade Média, sob forte influência da Igreja Católica e das classes mais abastadas, a entidade familiar só seria assim considerada se proveniente de um casamento celebrado por autoridade eclesiástica regularmente investida, e consubstanciado no consenso entre as partes, precedido da autorização das respectivas famílias, dada a repercussão econômica que o matrimônio acarretava.

No Brasil, essa ideia patriarcal e patrimonialista de família perdurou até o advento da Constituição Federal de 1988, a qual destituiu o paradigma patrimonial e patriarcal e instituiu o paradigma da Dignidade da Pessoa Humana como norteador do sistema jurídico, gerando assim toda uma revolução nos conceitos atinentes. Com efeito, o art. $1^{\circ}$, III da Magna Carta fez com que o ser humano, como eixo norteador, impusesse à personalidade um significado bem mais abrangente que o técnico-formal: a ideia de pessoa é vinculada ao ser humano em si considerado, como valor juridicamente tutelado no que se observa ser a personalidade uma decorrência da própria dignidade da pessoa humana.

\section{DO PRINCÍPIO DA DIGNIDADE HUMANA COMO ELEMENTO AGREGADOR DA FAMÍLIA}

Tepedino conceitua a personalidade como um feixe de características e atributos da pessoa humana e um bem objeto de tutela pelo ordenamento jurídico - pelo que a pessoa deve ser protegida de toda e qualquer agressão que venha a afetar a sua dignidade. E arremata:

[...] considerada como sujeito de direito, a personalidade não pode ser dele o seu objeto. [...] considerada, ao revés, como valor, tendo em conta o conjunto de atributos inerentes e indispensáveis ao ser humano (que se irradiam da personalidade), constituem bens jurídicos em si mesmos, dignos de tutela privilegiada. ${ }^{13}$

Assim, certo é se concluir que o ser humano é pessoa não porque tem personalidade, mas porque, por ser humano, possui atributos essenciais à vida que devem ser protegidos pelo ordenamento para que tenha um mínimo de dignidade e assim condições de vida em sociedade.

A esse mister, Szaniawski bem obtempera que o princípio da dignidade da pessoa humana contém um imperativo ordenatório a ser observado tanto pelos demais membros da sociedade quanto pelo Estado, de forma a que todos respeitem as condições mínimas essenciais de vida digna do ser humano, as quais, entre outras, perfariam a alimentação, a moradia, a educação, o trabalho, a honra, o respeito, a informação, a proteção à vida privada e a liberdade. ${ }^{14}$

De acordo com Amaral, o princípio da dignidade humana é um valor jurídico constitucionalmente positivado e, portanto, um marco jurídico no núcleo de proteção do sistema brasileiro dos direitos da personalidade: representa uma referência unificadora de todo o sistema de tutela da personalidade no ordenamento jurídico brasileiro. E bem conclui, asseverando que "o princípio da dignidade humana traduz o reconhecimento do valor da pessoa humana dotada dos direitos invioláveis que lhes são inerentes". ${ }^{15}$

Citado por Doneda, Larenz bem aduz a respeito:

\begin{abstract}
A proteção da personalidade humana no seu âmbito próprio [...] foi avaliada em geral como insuficiente após a Segunda Guerra Mundial. Após a experiência da Ditadura, havia surgido uma sensibilidade diante de toda forma de menosprezo da dignidade humana e da personalidade; ao mesmo tempo se percebeu que a possibilidade de realizar atos que representem um tal menosprezo, não somente por parte do Estado mas também por outras associações ou por pessoas privadas, tinham-se multiplicado, devido ao desenvolvimento da técnica moderna (por exemplo, fitas magnéticas, aparelhos de escuta, microcâmeras). ${ }^{16}$
\end{abstract}

12 FIÚZA, César. Direito civil: curso completo. 9. ed, 2. tiragem. Belo Horizonte: Del Rey, 2006, p. 939.

13 TEPEDINO, Gustavo. A tutela da personalidade no ordenamento civil constitucional positivo. In: TEPEDINO, Gustavo (Org.). Temas de Direito Civil. Rio de Janeiro: Renovar, 2004, p. 27.

14 SZANIAWSKI, Elimar. Direitos da Personalidade e sua tutela. 2. ed. rev. atual. e ampl. São Paulo: Revista dos Tribunais, 2005, p. 140.

15 AMARAL, Francisco. Direito Civil - introdução. 3. ed. Rio de Janeiro: Renovar, 2000, p. 249.

16 DONEDA, Danilo. Da privacidade à proteção de dados pessoais. Rio de Janeiro: Renovar, 2006, p. 64. 
Ou seja: a pessoa humana passou a ser considerada em razão de seus atributos humanísticos e não somente em face de sua aptidão para adquirir direitos e contrair obrigações.

Nessa linha de raciocínio é que a Constituição Federal reconheceu a entidade familiar como núcleo estrutural da sociedade (art. 226, caput e §§). Portanto se pode conceituar família como o grupo formado pelos pais unidos pelo casamento ou pela união estável e os filhos advindos de tal união (família biparental), por um dos pais e os respectivos filhos (família monoparental) ou, conforme aponta Fiúza (2006, p. 942), pela vida em comum de dois ou mais irmãos (família fraterna).

Entretanto qual o vínculo central que une os membros de uma família?

Os membros da entidade familiar vinculam-se por força de laços consanguíneos (descendência ou ascendência) ou legais (no caso dos adotados), mas mantêm tal união para a consecução de proteção mútua, desenvolvimento e evolução conjuntos e congêneres. Pode-se concluir que todo e qualquer assunto em que um particular envolva-se, mas de interesse direto e imediato da família, suscita a imagem desta como ente único.

Em outras palavras: se os membros de uma família unem-se e se reúnem por causa de um mesmo motivo juridicamente reconhecido e relevante, de forma contínua e duradoura e que interessa ao grupo como um todo, aí se verifica existência fática de uma coletividade que atua como um ente único.

Mais: visto reunirem-se os familiares de forma duradoura para o bem-estar coletivo - isto é, cada um dos integrantes do núcleo familiar age com vistas ao bem-estar de todos os demais -, ousa-se dizer que na família há o animus semelhante à affectio societatis, uma vez identificada a intenção coletiva em se perseguir e alcançar um objetivo em comum.

Isto posto, numa acepção simplista pode-se dizer que a família tem por premissa a reunião de seus membros em razão de um fato em comum: ainda que destituída de personalidade, a entidade familiar é vislumbrada a partir do pressuposto de que há um grupo unificado graças a um evento que os une de forma perene em determinada situação - característica que identifica os entes despersonalizados coletivos. ${ }^{17}$ Equivale a dizer: a família pode ser considerada um ente coletivo, dado que seus membros mantêm-se unidos com o propósito de resguardarem a dignidade particular e do grupo perante a sociedade.

Nesse mister, apropriado é o entendimento de Perlingieri:

[...] a harmonização das exigências individuais, a consideração das recíprocas interferências, a comunhão ou o concurso de interesses podem, frequentemente, fazer com que mais de uma situação subjetiva pareça de natureza, antes que individual, coletiva e familiar. ${ }^{18}$

Faça-se um comparativo entre duas hipóteses: penhora-se um imóvel em que quatro amigos são condôminos pro indiviso, mas apenas um deles é executado; penhora-se um imóvel em que pai, mãe e dois filhos residem, consubstanciando-se o mesmo em bem de família, mas em que apenas o pai é executado.

Conforme se depreende do exposto, em ambas as hipóteses ofende-se direito de um grupo em si considerado, pelo que a consequência lógica seria qualquer um de seus membros que não o devedor ter legitimidade para postular a referida tutela jurisdicional em nome do grupo. Assim é com o condomínio pro indiviso, em que qualquer um dos condôminos pode reivindicar a coisa de terceiros como se único dono fosse (CC, art. 1.314).

Idêntico raciocínio pode ser utilizado na segunda hipótese: se o interesse ofendido é aquele compartilhado em comum pelos membros da entidade familiar, observa-se então a figura da família como ente despersonalizado em razão da affectio societatis exposta. Esse interesse coletivo é reconhecido até mesmo pela legislação vigente: tem-se, por exemplo, o bem de família, cuja respectiva Lei n 8.009/90, de 29 de março de 1990 (Lei do Bem de Família), em seu art. $1^{\circ}$, assim preconiza:

17 Diz-se "coletivos" para se diferenciar do nascituro, o qual se poderia ser considerado ente despersonalizado "individual".

18 PERLINGIERI, Pietro. Perfis do Direito Civil: Introdução ao Direito Civil Constitucional. Rio de Janeiro: Renovar, 2000, p. 241. 
Art. $1^{\circ} 0$ imóvel residencial próprio do casal, ou da entidade familiar, é impenhorável e não responderá por qualquer tipo de dívida civil, comercial, fiscal, previdenciária ou de outra natureza, contraída pelos cônjuges ou pelos pais ou filhos que sejam seus proprietários e nele residam, salvo nas hipóteses previstas nesta lei. (grifo nosso)

Veja-se que a lei não menciona ser o imóvel próprio de um dos indivíduos da família, de um dos membros da entidade familiar ou algo semelhante. Fosse assim, e o artigo remeteria ao imóvel próprio do casal ou "de um dos membros da família", "de um dos componentes da entidade familiar", ou expressão congênere; ao se referir ao imóvel próprio "da entidade familiar", o legislador visualizou a família como um ente único e distinto de seus membros, unido por um interesse coletivo - in casu, a moradia, direito fundamental previsto no art. $6^{\circ}$ da Magna Carta.

Com efeito, não se pode dissociar a entidade familiar de seus membros individualmente considerados: a questão de ser ou não o imóvel bem de família é assunto afeto à entidade familiar como um todo indivisível, e não interesse isolado de cada um de seus componentes.

Os tribunais pátrios já firmaram entendimento nesse sentido:

BEM DE FAMÍLIA. IMÓVEL. IMPENHORABILIDADE. O único bem residencial de propriedade do executado constitui bem de família juridicamente protegido com cláusula de inalienabilidade, na forma do disposto na Lei 8.009/1990, sobre o qual não poderá incidir penhora, sendo que o objetivo da lei é proteger a entidade familiar e não o devedor. Ainda que ostente a qualidade de suntuoso (no caso, o imóvel penhorado foi avaliado em $R \$ 600.000,00$ ) tal circunstância não tem o condão de elidir a impenhorabilidade ora declarada, eis que o artigo $5^{\circ}$ da Lei 8.009/90 não exclui o imóvel residencial suntuoso do benefício da impenhorabilidade, eis que o escopo da referida norma legal é proteger o indivíduo e sua família, assegurando-lhes o direito à moradia. ${ }^{19}$ (grifo nosso).

Também se observa tal raciocínio na leitura do art. $1^{\circ}$ da Lei $n^{\circ} 5.859$, de 11 de dezembro de 1972 (Lei do Empregado Doméstico), o qual assim preleciona:

Art. $1^{\circ}$ Ao empregado doméstico, assim considerado aquele que presta serviços de natureza contínua e de finalidade não lucrativa à pessoa ou à família no âmbito residencial destas, aplica-se o disposto nesta lei. (grifo nosso)

Veja-se que, a exemplo do bem de família, a relação empregatícia doméstica admite a família como sujeito de direito, dado que o dispositivo mencionado considera duas modalidades de prestação de serviço como relação jurídica: do empregado à pessoa, e do empregado à família. Não fosse assim, e $o$ art. $1^{\circ}$ não mencionaria a família de forma destacada da pessoa como contratantes do empregado doméstico.

Portanto, quando se trata de discussão acerca do status de um bem como sendo de família ou da prestação de serviço doméstico como relação de emprego, o interesse não é de um ou alguns membros, mas de todos os integrantes da entidade familiar - ou, melhor dizendo, da família como ente único. Consequentemente, qualquer relação jurídica que redunde em ofensa ou desrespeito a tais prerrogativas (bem de família e empregador doméstico) levará à participação da família como um todo - isto é, como um sujeito de direito - num dos polos da relação jurídica, pelo que se verifica aí a família como ente despersonalizado.

\section{DA CAPACIDADE PROCESSUAL DA FAMÍLIA COMO ENTE DESPERSONALIZADO}

\section{DA FAMÍLIA COMO ENTE ÚNICO NA RELAÇÃO PROCESSUAL}

Suponha-se a seguinte situação: numa execução, um membro da família - o pai, por exemplo - ingressa com embargos de terceiro, alegando ser o imóvel penhorado bem de família; não o consegue provar e assim gera uma sentença de improcedência que transita em julgado.

19 BRASIL. Tribunal Regional do Trabalho da 3. região. Agravo de Petição n. 0086300-46.2006.5.03.0098. Kildare Silva Mendes e outros versus Antônio Ramiro de Araújo e outros. Relator Desembargador Marcelo Lamego Pertence. Belo Horizonte, 18 de março de 2010. Disponível em: <https://as1.trt3. jus.br/juris/detalhe.htm?conversationId=2844 >. Acesso em: 03 abr. 2012. 
Outro membro da família - a mãe, por exemplo - ingressa com novos embargos de terceiro, alegando o mesmo motivo (bem de família), mas desta vez obtém sentença favorável que vem a transitar em julgado.

Destarte, tem-se a situação paradoxal: em relação ao imóvel, há uma decisão transitada em julgado, que o declara não ser bem de família; outra, bem posterior à primeira, que o declara ser bem de família, em uma clara afronta ao princípio da coisa julgada.

Para resolver tamanha antinomia, traça-se um silogismo lógico: se uma sentença produz coisa julgada e, necessariamente, seus efeitos atingem a outras pessoas que não as qualificadas nos autos, mas com interesse material e processual no objeto da lide, estas não serão terceiros e sim componentes de uma das partes da lide, ainda que não expressamente dela constem. É tão verdade que, se o terceiro realmente fosse estranho à lide, a coisa julgada não Ihe alcançaria em razão de seus limites objetivos e subjetivos.

Assim, observa-se que a figura da família enquadra-se na definição de ente despersonalizado, em relações jurídicas que envolvam a discussão sobre bem de família: se o cerne da questão é a caracterização da coisa como bem de família, a entidade familiar em si considerada é que deve proceder à defesa de seus interesses. Em outras palavras: o interesse atingido não é isoladamente de um ou outro membro, mas da família enquanto entidade. Fosse de cada um dos membros, e estaria vulnerado o princípio da isonomia, na medida em que, verbi gratia, o exequente teria apenas uma chance de se penhorar o bem e uma família de pai, mãe e dez filhos, teria doze oportunidades de entrar com embargos.

Portanto se tem in casu que a figura do membro da família como terceiro é aparente: se um familiar ingressa com ação e o "terceiro interessado" faz parte da mesma família nos moldes do art. 226 e $\S \S d a C F$, tem interesse na causa e consequentemente integrará a lide, estando ou não qualificado nos autos. Isso deve ser necessariamente uma regra; o contrário redundaria em se admitir válida e legal a reserva mental em que, numa família de seis membros por exemplo, um entraria com embargos e os outros cinco esperariam o resultado, para respectivamente cada um entrar com embargos de terceiro para discutir a impenhorabilidade do bem de família, tão-somente para procrastinarem o feito ou para não cometerem os mesmos erros dos precedentes.

Mais ainda, porque os demais membros podem vir a se calar por ocasião da propositura dos embargos à execução ou de terceiros primeiramente movidos, em que ali se discute a questão de ser ou não o imóvel penhorado bem de família. Ora, tal omissão dolosa afronta o ordenamento jurídico por caracterizar reserva mental, vedada pelo art. 110 do Código Civil. ${ }^{20}$

Destarte, é de se aplicar o brocardo latino nemo propriam auditur turpitudinem allegans ${ }^{21}$ : se o membro da família queda-se silente por ocasião da discussão sobre o enquadramento ou não do bem de família ou sobre a relação empregatícia doméstica, não pode posteriormente em sede de Embargos de Terceiro querer discutir novamente o que já fora decidido e transitado em julgado em relação à entidade familiar da qual faz parte.

A esse mister, o escólio de Santos é elucidativo:

A verdadeira finalidade do processo, como instrumento destinado à composição da lide, é fazer justiça, pela atuação da vontade da lei ao caso concreto. Para obviar a possibilidade de injustiças, as sentenças são impugnáveis por via de recursos, que permitem o reexame do litígio e a reforma da decisão. A procura da justiça, entretanto, não pode ser indefinida, mas deve ter um limite, por exigência de ordem pública, qual seja a estabilidade dos direitos, que inexistiria se não houvesse um termo além do qual a sentença se tornou imutável. ${ }^{22}$ (grifo nosso)

Portanto, por uma questão de ordem social e segurança jurídica, haverá situações em que a sentença deve alcançar a todos os membros da família e não somente àquele que se manifestou nos autos, eis que o interesse não fora exclusivamente individual, mas antes da família considerada

20 Art. 110: "A manifestação de vontade subsiste ainda que o seu autor haja feito a reserva mental de não querer o que manifestou, salvo se dela o destinatário tinha conhecimento".

21 Numa livre tradução nossa: ninguém se vale da própria torpeza para alegar prejuízo.

22 SANTOS, Moacyr Amaral. Primeiras Linhas de Direito Processual Civil. 17. ed. São Paulo: Saraiva, 1998, vol. 3, p. 45. 
em sua totalidade: quando um integrante da família intentar ação cujo interesse processual fosse diretamente ligado aos demais, dever-se-ia estender os efeitos do decisum aos demais integrantes familiares - o que se discutirá a seguir.

\title{
O PRINCÍPIO DA COISA JULGADA EM RELAÇÃO A TERCEIROS
}

Quando as pessoas não solucionam entre si conflitos de interesse, batem às portas do Poder Judiciário para a respectiva tutela jurisdicional. Nesse sentido, o art. 468 da Lei n 5.689/73 (Código de Processo Civil) delimita o alcance da força cogente do decisum nos limites da lide e das questões decididas. Nas palavras de Melo Almeida a sentença:

\begin{abstract}
É o ato pelo qual o juiz decide a lide. Também, pode-se conceituar a sentença como sendo o ato processual por meio do qual o juiz aprecia as pretensões punitivas e de liberdade, aplicando o direito positivo material no situação concreta a ele submetida no exercício jurisdicional. Não pode a sentença apresentar-se como ato de mero arbítrio do juiz. Impõe-se que seja resultado de um processo lógico de convencimento e demonstração do modo com que se chegou, dentro do ordenamento jurídico, essencialmente constitucional e diante dos elementos probatórios, à conclusão judicial. ${ }^{23}$
\end{abstract}

A coisa julgada tem dois aspectos - formal e material -, de igual e grande relevância. Quanto à primeira (coisa julgada formal), proferida a sentença e esgotados todos os recursos admissíveis ao caso concreto, operou-se uma decisão, porém não se discutiu o mérito, conforme descrito no art. 267 do CPC.

Por outro lado, a coisa julgada material torna impossível a rediscussão do mérito entre as partes e terceiros, visto a sentença já ter resolvido definitivamente nesse sentido; a coisa julgada material é, então, a sentença da qual não cabe mais recurso (CPC, art. $301 \S 3^{\circ}$, segunda parte). Assim, por uma questão de manutenção da ordem social, uma vez não recorrida no respectivo prazo, a sentença torna-se definitiva, imutável e indiscutível, e bem assim a matéria por ela tratada e decidida - ressaltando-se a ação rescisória a única hipótese de desconstituição da coisa julgada material, nas restritas hipóteses do art. 485 do CPC.

Nas palavras de Fidélis:

Incertas ficariam as relações sociais, com a possibilidade de perpetuação dos litígios, se as decisões jurisdicionais não adquirissem a característica de definitividade. Está é a razão pela qual a lei criou o instituto da coisa julgada material, que, inclusive, é prevista, constitucionalmente: Constituição Federal, art. 50, XXXVI. "A lei não prejudicará o direito adquirido, o ato jurídico perfeito e a coisa julgada". ${ }^{24}$

Acerca de tal mister, dois são os aspectos de seus limites: objetivo e subjetivo. Quanto ao primeiro, observa-se a situação em que uma sentença não pode adentrar no mérito de questão já decidida por outra sentença irrecorrível, ou seja, "quando se repete ação que já foi decidida por sentença, de que não caiba recurso" (CPC, art. $301 \S 3^{\circ}$, segunda parte), ressaltando-se a necessidade de identidade de ações: "uma ação é idêntica à outra quando tem as mesmas partes, a mesma causa de pedir e o mesmo pedido" (CPC, art. 301, §2).

Tocante ao aspecto subjetivo, este se refere aos destinatários dos efeitos da sentença irrecorrível. Nesse sentido, pode a decisão ter efeito inter partes se os efeitos restringirem-se somente às partes que ocuparam os polos da lide; ou erga omnes, se além das partes litigantes terceiros também forem afetados pelos efeitos irrecorríveis da sentença, conforme preceitua o art. 472 do CPC:

Art. 472 - A sentença faz coisa julgada às partes entre as quais é dada, não beneficiando, prejudicando terceiros. Nas causas relativas ao estado de pessoa, se houverem sido citados no processo, em litisconsórcio necessário, todos os interessados, a sentença produz coisa julgada em relação a terceiros.

Exemplo do alcance a terceiros é dado por Nery e Nery Júnior:

Sentença e coisa julgada. Os efeitos da sentença proferida entre as partes originárias, incluído aqui o alienante da coisa ou direito litigioso, atingirão todos os adquirentes. Se houver cadeia

23 MELO ALMEIDA, Magda Gonçalves. Efetividade da coisa julgada. Belo Horizonte: Casa de Artes, 2003, p. 19.

24 FIDELIS, Ernane. Manual de Processo Civil. 10. ed. São Paulo: Saraiva, 2003, v. 1, p. 555. 
Prosseguem os autores:

\begin{abstract}
Efeito expansivo da liminar ou sentença. A medida liminar ou sentença proferida em ação civil pública ou ação coletiva, pela circunstância concreta, pode atingir número elevado de pessoas residentes por todo o país, notadamente quanto aos efeitos erga omnes ou ultra partes da coisa julgada (CDC 103). Neste caso, os efeitos subjetivos da sentença se produzirão onde quer que seus destinatários se encontrem. É possível que, por exemplo, liminar ou sentença de juiz estadual tenha de produzir efeitos em outro Estado da federação. Não se trará de jurisdição nem de competência, mas de limites subjetivos da coisa julgada. [...] Terceiros interessados. Estes serão atingidos reflexamente pela coisa julgada material. É o caso, v.g., daquele que adquire o direito ou objeto litigioso, pois mesmo que não ingresse no processo com sucessor do alienante, fica sujeito aos efeitos da coisa julgada (CPC $\left.42 \S 3^{\circ}\right) .{ }^{26}$
\end{abstract}

Destarte, pode acontecer que terceiros venham a ser atingidos pela coisa julgada, ainda que por via reflexiva. No caso em tela, mesmo se a família não tiver personalidade jurídica, uma vez considerada ente único, todos os seus membros deverão se curvar aos efeitos de sentença em ação que considere a entidade familiar como sujeito de direito processual, interessados que são no respectivo desfecho da lide. Ainda assim, o CPC, em seu art. $301, \S \S 1^{\circ}$ e $2^{\circ}$, preconiza a existência da coisa julgada pela presença dos elementos da ação: mesmas partes, mesma causa de pedir e mesmo pedido. Portanto, sendo a entidade familiar um ente único conseqüentemente, verifica-se a tríplice identidade mencionada pelo art. $301, \S \S 1^{\circ}$ e $2^{\circ}$, do CPC.

É dizer: se a sentença transita em julgado e beneficia a terceiros - como no caso da declaração da impenhorabilidade do bem de família -, então esse é o alcance da coisa julgada: a entidade familiar como um todo uno, e não os membros individualmente considerados. Assim, idêntico alcance deve ser presumido quanto ao prejuízo: deve-se enxergar a entidade familiar como um todo único, e não os membros individualizados, no tocante à sentença transitada em julgado que declarou não ser bem de família o imóvel em questão.

Fux brilhantemente explana sobre o assunto, ao afirmar que:

A situação de conflito submetida ao Judiciário tem os seus protagonistas, e a decisão, a fortiori, seus destinatários. Outrossim, a sentença não vive isolada no mundo jurídico, ressoando possível que uma decisão reste por atingir a esfera jurídica de pessoas que não participaram do processo. ${ }^{27}$ (grifo nosso)

Sobre tal raciocínio, já há entendimento jurisprudencial nesse sentido, verbis:

IMÓVEL. BEM DE FAMÍLIA. EMBARGOS DE TERCEIRO. COISA JULGADA. Se no processo principal já restou decidido que o imóvel em que reside o executado e seus familiares não constitui bem de família, tal decisão tem força de coisa julgada em relação a toda entidade familiar, inclusive em relação aos filhos que ali residem. Nesse caso, parte, do ponto de vista processual, para efeito de reconhecimento da tríplice identidade que caracteriza a coisa julgada, é a entidade familiar, em cujo âmbito se incluem os filhos do executado. Para que não haja qualquer dúvida quanto a este aspecto, basta proceder ao raciocínio inverso e considerar que se a decisão proferida nos autos principais tivesse declarado como bem de família o imóvel penhorado, tal decisão beneficiaria não só o casal, mas todos os demais membros da família que residem no imóvel. ${ }^{28}$ (grifo nosso)

O voto do Exmo. Relator Desembargador Koury é elucidativo:

Pretendem os agravantes a reforma da decisão de fls. 73/75, que extinguiu o processo sem julgamento do mérito, em virtude do acolhimento da preliminar de coisa julgada. Alegam que não

25 NERY, R. M. A.; NERY JUNIOR, Nelson. Código de processo civil comentado e legislação extravagante - atualizado até $1^{\circ}$ de março de 2006. 9. ed. rev., atual. e ampl. São Paulo: Revista dos Tribunais, 2006, p. 217.

26 NERY, R. M. A.; NERY JUNIOR, Nelson. Código de processo civil comentado e legislação extravagante. p. 617.

27 FUX, Luiz. Curso de direito processual civil: processo de conhecimento, processo de execução e processo cautelar. 2. ed. Rio de Janeiro: Forense, 2004, p. 832.

28 BRASIL. Tribunal Regional do Trabalho da 3. Região. Agravo de Petição n. 00701-2004-043-03-00-2. Relator: Desembargador Luiz Ronan Neves Koury. Belo Horizonte, 26 de agosto de 2004. Disponível em: <https://as1.trt3.jus.br/juris/detalhe.htm?conversationId=2506>. Acesso em: 03 abr. 2012. 
figuraram como parte nos autos em que se discutiu a legalidade da penhora do imóvel descrito no auto de fl. 12 e, na condição de terceiros prejudicados, não pode sofrer os efeitos da mencionada decisão, invocando o art. 472 do CPC. Asseveram que na condição de filhos do executado, Glycon Agostinho, não podem ser tidos como herdeiros ou sucessores, vez que seu pai ainda está vivo. Sustentam que o imóvel penhorado constitui bem de família, sendo ilegal a penhora realizada, havendo decisões judiciais em prol de sua tese. Sem razão. Contrariamente ao afirmado pelos recorrentes, os efeitos da decisão proferida nos autos principais, com referência aos embargos à execução opostos pelo seu pai, Glycon Agostinho, têm repercussão sobre os mesmos, levando-se em consideração que fazem parte da entidade familiar residente no imóvel objeto da controvérsia. Para melhor elucidar a questão, basta fazer o raciocínio inverso e considerar que se a decisão proferida nos autos principais tivesse declarado que o imóvel penhorado representava bem de família, é evidente que ela beneficiaria não só o casal, mas todos os demais membros da família que residem no imóvel. ${ }^{29}$ (grifo nosso)

Ainda:

Agravo de petição. Coisa julgada. Alcance. Transitada em julgado a sentença que declarou subsistente a penhora realizada sobre bem imóvel, por considerar caracterizada a hipótese de fraude à execução, resta imutável aquela decisão, não podendo a matéria ser rediscutida em novos embargos de terceiro, agora apresentados pela cônjuge do anterior embargante, na condição de meeira. Agravo de petição a que se nega provimento. ${ }^{30}$ (grifo nosso)

Em tal acórdão, a Exma. Relatora Desembargadora Sampaio, em voto acompanhado unanimemente pela Turma, sabiamente decidiu:

Trata-se, a toda evidência, de questão impregnada pelo caráter de imutabilidade, conferido à decisão não mais sujeita a recurso ordinário ou extraordinário, notadamente porque a embargante/ recorrente é membro da mesma sociedade conjugal do anterior embargante, nada levando a crer que não tivesse ciência da ação preteritamente ajuizada; antes ao contrário, de modo a justificar a defesa da sua meação. ${ }^{31}$ (grifo nosso)

Ainda:

APELAÇÃO CÍVEL - EMBARGOS DE TERCEIRO - IMPENHORABILIDADE DE BEM DE FAMÍLIA - MATÉRIA ACOBERTADA PELO MANTO DA COISA JULGADA. A alegação de impenhorabilidade do bem de família já decidida em sede de Embargos de devedor, com decisão transitada em julgado, se submete à coisa julgada, que tem como um dos principais efeitos o chamado efeito negativo ou obstativo, que impede que o juiz decida novamente aquilo que já foi objeto de outra decisão. ${ }^{32}$ (grifo nosso)

A Exma. Relatora Desembargadora Marques, em voto acompanhado unanimemente pela Câmara Cível, é elucidativa em seu voto:

Pois bem. A coisa julgada, qualidade da sentença que torna indiscutível o conteúdo daquilo que foi decidido, tem como um dos principais efeitos o chamado efeito negativo ou obstativo, que impede que o juiz decida novamente aquilo que já foi objeto de outra decisão. Observo que a questão suscitada no presente feito, qual seja, a impenhorabilidade do imóvel por constituir bem de família, já foi objeto de análise tanto em sede de Embargos de devedor (fls. 38/58 dos autos de execução), quanto de Agravo de Instrumento (fls. 111/116), tendo no referido recurso sido decidido que 'a decisão agravada apresenta-se irretorquível também no que concerne à alegação dos agravantes de se tratar de bem de família, vez que como demonstrado pelo agravado, tal matéria encontra-se sob o manto da coisa julgada, havendo a

29 BRASIL. Tribunal Regional do Trabalho da 3. Região. Agravo de Petição n. 00701-2004-043-03-00-2, de Uberlândia. Voto do Relator Desembargador Luiz Ronan Neves Koury.

30 BRASIL. Tribunal Regional do Trabalho da 6. Região. Recurso Ordinário n. 00341-2002-391-06-00-9, de Salgueiro. Relatora: Desembargadora Valéria Gondim Sampaio. Acórdão de 17 de dezembro de 2002. Disponível em: <http://www.trt6.jus.br/portal/portal/default/Jurisprudencia/ acordaosInteiro T eor;jsessionid=617F481FE44D7D5D0CD52399F33E39EF.internet-node1>. Acesso em: 04 abr. 2012.

31 BRASIL. Tribunal Regional do Trabalho da 6. Região. Recurso Ordinário n. 00341-2002-391-06-00-9, de Salgueiro. Voto da Relatora.

32 BRASIL. Tribunal de Justiça de Minas Gerais. Apelação Cível n 1.0287.05.021666-5/001, de Guaxupé. Relatora: Desembargadora Selma Marques. Belo Horizonte, 28 de março de 2007. Disponível em: <http://www.tjmg.jus.br/juridico/jt_/inteiro_teor.jsp?tipoTribunal=1\&comrCodigo $=287 \&$ ano $=5 \&$ txt_p rocesso $=21666 \&$ complemento $=1 \&$ sequencial $=0 \&$ palavrasConsulta $=\&$ todas $=\&$ expressao $=\& q u a l q u e r=$ \&sem $=$ \&radical $=>$. Acesso em: 04 abr. 2012. 
sentença de fls. 65/74 TA e o acórdão que a confirmou, de fls. 75/85 TA, afastado a aplicação da Lei 8.009/90 por completa falta de prova de haver qualquer residência no imóvel, e ainda, por nele funcionar firma individual do filho dos executados com atividade comercial" (fls. 116 dos autos de execução). Assim, encontra-se a referida questão acobertada pelo manto da coisa julgada, razão pela qual acertada a decisão de primeiro grau que extinguiu o feito sem análise do mérito. ${ }^{33}$ (grifo nosso)

Constata-se assim que, caracterizada a família como ente despersonalizado e destarte sujeito de direito às relações jurídicas expressamente comentadas, uma vez transitada em julgado decisão que afeta ao interesse da família nas hipóteses de discussão sobre bem de família e relação empregatícia doméstica, a respectiva coisa julgada impõe-se sobre todos os componentes da entidade familiar da entidade familiar como parte, e não somente um de seus membros individualmente considerado - no caso, quem por ela se manifestou nos autos.

\section{DA RESTRIÇÃO DA CONFIGURAÇÃO DA FAMÍLIA COMO ENTE ÚNICO}

Quanto aos entes despersonalizados, consubstanciam-se os mesmos em entidades destituídas de personalidade por se entender que, por figurarem apenas em determinadas e ocasionais situações jurídicas, não necessitariam de aptidão plena para serem titulares de direitos e obrigações - razão pela qual o sistema jurídico confere-Ihes tal faculdade somente em determinados casos. Em face de tal mister, somente em determinadas ocasiões especificadas pela lei os entes despersonalizados participariam de uma relação jurídica.

Posto de outra forma: num contexto jurídico-formal, os entes despersonalizados possuem tal aptidão limitada a determinadas relações jurídicas especificadas tanto pela legislação quanto por sua própria natureza.

Destarte, não se quer dizer que a família seria ente único em toda e qualquer situação jurídica: isso representaria um retrocesso, regredindo a figura familiar à matriz institucionalista do Código Civil de 1916, e bem assim forçaria uma configuração da família como pessoa, eis que apta a todos os atos da vida civil. O que se busca demonstrar é a configuração da família como sujeito de direito em situações nas quais o interesse tutelado seja de todos os membros indistintamente, tal qual a própria legislação pátria já especificou - por exemplo, por ocasião do art. $1^{\circ}$ da Lei do Bem de Família e do art. $1^{\circ}$ da Lei do Empregado Doméstico - e porventura virá a especificar. Daí o dizer ser a família ente despersonalizado, justamente porque seria ente único somente em situações autorizadas pela lei.

\section{DA NECESSIDADE DE REVISÃO DO ART. 12 DO CÓDIGO DE PROCESSO CIVIL}

À medida que a sociedade evolui, seus paradigmas e necessidades alteram-se: o que é proibido ou anormal hoje poderá não o ser amanhã e vice-versa. Assim também ocorre com as normas jurídicas, as quais se reformulam de tempos em tempos para continuarem a ser úteis à manutenção da convivência harmônica entre os membros da sociedade.

Com efeito, segundo Ferraz Júnior, a sociedade "representa um sistema de interações, comportamentos mutuamente dirigidos e referidos uns aos outros, formando uma rede de relações, definindo comportamento como um estar em situação" ${ }^{34}$; assim, quando tais interações e comportamentos adotam novas tendências e parâmetros, verifica-se a necessidade de mudança e readequação da norma. Nesse sentido, Kelsen bem aduz:

NORMA quer significar que algo deve ser ou acontecer, especialmente que um homem se deve conduzir de determinada maneira. É este o sentido que possuem determinados atos humanos que intencionalmente se dirigem à conduta de outrem. Dizemos que se dirigem intencionalmente a conduta de outrem não só quando em conformidade com seu sentido, prescrevem (comandam) essa conduta, mas também quando a permitem e, especialmente, quando conferem o poder de

33 BRASIL. Tribunal de Justiça de Minas Gerais. Apelação Cível no 1.0287.05.021666-5/001, Relatora Desembargadora Selma Marques.

34 FERRAZ JÚNIOR, Tércio Sampaio. Introdução ao Estudo do Direito: Técnica, decisão, dominação. 2. ed. São Paulo: Atlas, 1994, p. 103-104. 
a realizar, isto é, quando a outrem é atribuído um determinado poder, especialmente o poder de ele próprio estabelecer normas. Tais atos são - entendidos neste sentido - atos de vontade. ${ }^{35}$

Portanto as normas mudam de acordo com a evolução histórica, política e social da sociedade. Nesse sentido, verificado que a família hodiernamente constitui um ente despersonalizado, mister se faz o reconhecimento legislativo de sua capacidade processual conforme a jurisprudência acertadamente já o faz. Em face da aludida inovação social e jurídica, é preciso incluir-se um inciso no art. 12 do CPC, prevendo a família como dotada de capacidade processual.

À guisa de sugestão, poder-se-ia inserir um inciso $X$ da seguinte forma:

Art. 12. Serão representados em juízo, ativa e passivamente:

I - a União, os Estados, o Distrito Federal e os Territórios, por seus procuradores;

II - o Município, por seu Prefeito ou procurador;

III - a massa falida, pelo síndico;

IV - a herança jacente ou vacante, por seu curador;

V - o espólio, pelo inventariante;

VI - as pessoas jurídicas, por quem os respectivos estatutos designarem, ou, não os designando, por seus diretores;

VII - as sociedades sem personalidade jurídica, pela pessoa a quem couber a administração dos seus bens;

VIII - a pessoa jurídica estrangeira, pelo gerente, representante ou administrador de sua filial, agência ou sucursal aberta ou instalada no Brasil (art. 88, parágrafo único);

IX - o condomínio, pelo administrador ou pelo síndico;

X - a família, assim considerada nos moldes do art. 226 e §§ da Constituição Federal, por qualquer de seus membros, quando houver interesse comum dos familiares.

Tal inciso só viria a sacramentar o que já é realidade jurisprudencial: a família é um ente despersonalizado e pode ser parte numa relação material e consequentemente numa processual.

\section{CONSIDERAÇÕES FINAIS}

Do exposto, verificou-se ter a família aptidão para figurar como ente único, ainda que despersonalizado. Por consequência, em certos casos a família tem aptidão para figurar como sujeito de direito numa relação jurídica material e, se tiver seu interesse violado ou violar a interesses alheios, terá aptidão para figurar como parte numa relação jurídica processual.

Nesse mister, restou verificada a necessidade de se enxergar a família em tais casos como ente único: do contrário, proteger o interesse de um grupo em si considerado, mas oportunizar capacidade processual para os membros individualmente considerados redundaria em violação do princípio da igualdade em relação à parte ex adverso. Com efeito, numa família de dez membros haveria dez chances de se postular um interesse da família em contraposição a uma única chance de defesa da outra parte, ao passo que, se a decisão fosse favorável à família, tal beneficiaria a todos os membros indistintamente.

Daí a necessidade de se alterar o art. 12 do CPC, atualizando a legislação à realidade jurisprudencial e se conferindo à família capacidade processual, conforme a sugestão aludida: acrescentar-se-ia um inciso $X$, segundo o qual seria representada ativa e passivamente "a família, assim considerada nos moldes do art. 226 e $\S \S$ da Constituição Federal, por qualquer de seus membros, quando houver interesse comum dos familiares".

35 KELSEN, Hans, Teoria pura do direito. Tradução de João Baptista Machado. 6. ed. São Paulo: Martins

Fontes, 1998, p. 5. 
Ressalte-se que, conforme já dito, a família seria considerada ente único somente em situações pontuais, em que o interesse tutelado fosse de todos os membros indistintamente, tal qual a própria legislação pátria já especificou - por exemplo, por ocasião do art. $1^{\circ}$ da Lei do Bem de Família e do art. $1^{\circ}$ da Lei do Empregado Doméstico -, não se retrocedendo, portanto, à visão liberalistainstitucionalista do Código Civil de 1916.

Faça-se justiça, mas à luz da razão e do direito.

\section{REFERÊNCIAS}

ALPA, Guido. Istituzioni di Diritto Privato. 2. ed. Torino: UTET, 1997.

ALVES, José Carlos Moreira. Direito Romano. Rio de Janeiro, Forense, 1996.

AMARAL, Francisco. Direito Civil - introdução. 3. ed. Rio de Janeiro: Renovar, 2000.

ARISTÓTELES. Política. Tradução Pedro Constantin Tolens. São Paulo: Martin Claret, 2001.

BRASIL. Lei n. 3.071, de 01 de janeiro de 1916. Código Civil de 1916. Disponível em: <http://www. planalto.gov.br/ccivil_03/leis/L3071.htm>. Acesso em: 15 fev. 2012.

BRASIL. Lei n. 5859, de 11 de dezembro de 1972. Dispõe sobre a profissão de empregado doméstico e dá outras providências. Disponível em: <http://www.planalto.gov.br/ccivil_03/LEIS/L5859.htm>. Acesso em: 20 fev. 2012.

BRASIL. Lei n. 5.869, de 11 de janeiro de 1973. Código de Processo Civil. Disponível em: <http:// www.planalto.gov.br/ccivil_03/LEIS/L5869compilada.htm>. Acesso em: 18 fev. 2012.

BRASIL. Lei n. 8.009, de 29 de março de 1990. Dispõe sobre a impenhorabilidade do bem de família. Disponível em: <http://www.planalto.gov.br/ccivil_03/LEIS/L 8009.htm>. Acesso em: 20 fev. 2012.

BRASIL. Lei n. 8.078, de 11 de setembro de 1990. Código de Defesa do Consumidor. Disponível em: <http://www.planalto.gov.br/ccivil_03/leis/L8078compilado.htm>. Acesso em 10 fev. 2012.

BRASIL. Tribunal de Justiça de Minas Gerais. Apelação Cível no 1.0287.05.021666-5/001, de Guaxupé. Carmélia de Melo Chueiri versus Banco do Brasil S/A. Relatora: Desembargadora Selma Marques. Belo Horizonte, 28 de março de 2007. Disponível em: <http://www.tjmg.jus.br/juridico/jt_inteiro_teor. jsp?tipoTribunal $=1 \&$ comrCodigo $=287 \&$ ano $=5 \&$ txt_processo $=21666 \&$ complemento $=1 \&$ sequencial $=0 \& p$ alavrasConsulta $=\&$ todas $=\&$ expressao $=\&$ qualquer $=\&$ sem $=\&$ radical $=>$. Acesso em: 04 abr. 2012.

BRASIL. Tribunal Regional do Trabalho da 3. Região. Agravo de Petição n. 00701-2004-043-03-00-2, de Uberlândia. Alexander Santos Agostinho e outro versus Cássio Silva Soares e Metalúrgica União Ltda. Relator: Desembargador Luiz Ronan Neves Koury. Belo Horizonte, 26 de agosto de 2004. Disponível em: <https://as1.trt3.jus.br/juris/detalhe.htm?conversationId=2506>. Acesso em: 03 abr. 2012.

BRASIL. Tribunal Regional do Trabalho da 3. região. Agravo de Petição n. 0086300-46.2006.5.03.0098. Kildare Silva Mendes e outros versus Antônio Ramiro de Araújo e outros. Relator Desembargador Marcelo Lamego Pertence. Belo Horizonte, 18 de março de 2010. Disponível em: <https://as1.trt3.jus.br/juris/ detalhe.htm? conversationId=2844>. Acesso em: 03 abr. 2012.

BRASIL. Tribunal Regional do Trabalho da 6. Região. Recurso Ordinário n. 00341-2002-391-06-00-9, de Salgueiro. Andréa Mota de Carvalho Roza versus Maria Lourdes Januário Pereira e outros. Relatora: Desembargadora Valéria Gondim Sampaio. Recife, 17 de dezembro de 2002. Disponível em: <http:// www.trt6.gov.br/ consultaOnline2/index.php?metodo $=$ consultatstcompleto2a\&chaveprocesso $=\mathrm{AP} \% 20$ \%200217602>. Acesso em: 04 abr. 2012.

CANOTILHO, José Joaquim Gomes. Direito Constitucional e Teoria da Constituição. 2. ed. Coimbra: Almeidina, 1998.

CUNHA, Alexandre Santos da. Dignidade da pessoa humana: conceito fundamental do direito civil. In: MARTINS-COSTA, Judith; BRANCO, Gerson Luiz Carlos. Diretrizes teóricas do Novo Código Civil Brasileiro. São Paulo: Saraiva, 2002.

DE CUPIS, Adriano. Os direitos da personalidade. trad. Adriano Vera Jardim e Antonio Miguel Caeiro. Lisboa: Livraria Morais, 1961. 
DINIZ, Maria Helena. Compêndio de Introdução à Ciência do Direito. 15. ed. São Paulo: Saraiva, 2003.

v. 1.

Curso de Direito Civil Brasileiro: teoria geral do direito civil. 24. ed. São Paulo: Saraiva, 2007,

DONEDA, Danilo. Da privacidade à proteção de dados pessoais. Rio de Janeiro: Renovar, 2006.

FERRAZ JÚNIOR, Tércio Sampaio. Introdução ao Estudo do Direito: Técnica, decisão, dominação. 2. ed. São Paulo: Atlas, 1994.

FIDELIS, Ernane. Manual de Processo Civil. 10. ed. São Paulo: Saraiva, 2003, v. 1.

FIÚZA, César. Direito civil: curso completo. 9. Ed. 2. tiragem. Belo Horizonte: Del Rey, 2006.

FUX, Luiz. Curso de direito processual civil: processo de conhecimento, processo de execução e processo cautelar. 2. ed. Rio de Janeiro: Forense, 2004.

GOMES, Orlando. Introdução ao direito civil. 16. ed. Rio de Janeiro: Forense, 2000.

KELSEN, Hans. Teoria pura do direito. Tradução de João Baptista Machado. 6. ed. São Paulo: Martins Fontes, 1998.

LORENZETTI, Ricardo. Fundamentos do direito privado. Tradução de Vera Jacob de Fradera. São Paulo: Revista dos Tribunais, 1998.

MARTINS COSTA, Judith Hofmeister. O Direito Privado como um "sistema em construção": as cláusulas gerais no Projeto do Código Civil brasileiro. Jus Navigandi, maio de 2000. Disponível em: <http://jus2. uol.com.br/doutrina/texto.asp? id=513 > . Acesso em 01 fev. 2012.

MELO ALMEIDA, Magda Gonçalves. Efetividade da coisa julgada. Belo Horizonte: Casa de Artes, 2003.

MIRANDA, Jorge. Manual de direito constitucional. 3. ed. Coimbra: Coimbra Editora, 2000, tomo 4.

MORAES, Alexandre de. Direito Constitucional. São Paulo: Atlas, 2006.

NERY, Rosa Maria de Andrade; NERY JUNIOR. Código de processo civil comentado e legislação extravagante - atualizado até $1^{\circ}$ de março de 2006. 9. ed. rev., atual. e ampl. São Paulo: Revista dos Tribunais, 2006.

NOGUEIRA, Jenny Magnani de O. A Instituição da Família em A Cidade Antiga. In WOLKMER, Antonio Carlos (Org.). Fundamentos de História do Direito. 5. ed. Belo Horizonte: Del Rey, 2010.

PERLINGIERI, Pietro. Perfis do Direito Civil: Introdução ao Direito Civil Constitucional. Rio de Janeiro: Renovar, 2000.

SANTOS, Moacyr Amaral. Primeiras Linhas de Direito Processual Civil. 17. ed. São Paulo: Saraiva, 1998, vol. 3.

SZANIAWSKI, Elimar. Direitos da Personalidade e sua tutela. 2. ed. rev. atual. e ampl. São Paulo: Revista dos Tribunais, 2005.

TEPEDINO, Gustavo. A tutela da personalidade no ordenamento civil constitucional positivo. In: TEPEDINO, Gustavo (Org.). Temas de Direito Civil. Rio de Janeiro: Renovar, 2004.

VENOSA, Sílvio de Salvo. Direito civil: parte geral. 5. ed. São Paulo: Atlas, 2005. 